\title{
Impact of an Enterprise's Company Profile on Social Media on Purchasing Decisions of Representatives of Generation Z
}

\author{
Anna KOROMBEL and Olga ŁAWIŃSKA \\ Czestochowa University of Technology, Poland
}

Correspondence should be addressed to: Anna KOROMBEL; anna.korombel@wz.pcz.pl

Received date: 4 March 2019; Accepted date:29 April 2018; Published date: 3 July 2019

Academic Editor: Eva Benková

Copyright (C) 2019. Anna KOROMBEL and Olga ŁAWIŃSKA. Distributed under Creative Commons CC-BY 4.0

\begin{abstract}
Social media - especially for young generation $\mathrm{Z}$ - have become an essential tool for establishing private, professional and consumer relations. People from generation Z constitute an increasingly demanding group of customers. The aim of the paper is to find out how representatives of generation $\mathrm{Z}$ assess the creation of a company profile by an enterprise on social media, and to indicate the actions taken by an enterprise on its social media company profile that had the biggest impact on representatives of generation Z's decisions to make a purchase. As well as literature review, a survey was conducted among 233 students - representatives of generation Z. Analysis of the gathered empirical data gave grounds for verifying the research hypotheses formulated in the paper and concluding that most of the surveyed representatives of generation $\mathrm{Z}$ consider a company profile to be a valuable source of information about the company and its offer. Moreover, actions taken by entrepreneurs on their company profiles impact purchasing decisions of representatives of generation Z. Actions with the biggest impact on their purchasing decisions include: publishing information about promotion and receipt of a discount coupon. Additionally, the strength of the relationships between the analysed variables and the respondent's gender and place of residence was verified.
\end{abstract}

Keywords: social media, company profile, enterprise/brand, generation Z.

Cite this Article as: Anna KOROMBEL and Olga ŁAWIŃSKA (2019)," Impact of an Enterprise's Company Profile on Social Media on Purchasing Decisions of Representatives of Generation Z", IBIMA Business Review, Vol. 2019 (2019), Article ID 671964, DOI: 10.5171/2019.671964 


\section{Introduction}

Social media provide generation $\mathrm{Z}$ consumers with new ways to establish contacts with enterprises, acquire information from them, present their opinions - both positive and negative - and assess and comment on enterprises, their products and services. Hence, integrating the customer service department with social media is becoming a necessity for enterprises wishing to provide highest quality services and products (Passios and Pleasant, 2012). Consumer educators and businesses alike should consider the differences between generations as they work with consumers across generations (Wuest et al., 2008).

Social media have an impact on the consumer's final decision to make a purchase online (Evans, 2010). Electronic marketing, and more specifically social media marketing, provides marketers through social networking sites - with an Internet platform to promote brand image and awareness, and it generates traffic between an organisation's official websites and social platforms (Evans, 2010). Social media give brands a voice, global audience and flexibility in reaching the target group (Evans and McKee, 2010; Ramsunder, 2011). Enterprises increasingly use social networking sites for business purposes - to build their image, win customers, sell online and maintain long-term relations. In order to be effective, the content designed to promote brand on a company profile has to be relevant to customers' life (Kotler et al., 2017).

The aim of the paper is to find out how representatives of generation $\mathrm{Z}$ assess the creation of a company profile by an enterprise on social media, and to indicate the actions taken by an enterprise on its company profile on social media that had the biggest impact on representatives of generation Z's decision to make a purchase.

\section{Literature Review}

\section{What is a company profile?}

Over several years, the model of the functioning of the Internet has changed from static viewing of websites to an interactive model, where users actively impact the content being published. This resulted from the IT revolution that occurred with the rise of social networking sites (the most important of them is Facebook, which appeared on 4 February 2004) and applications that were made available on them. A. M. Kaplan and M. Haenlein (2010) define social media as "a group of applications based on Internet solutions that rely on ideological and technological bases of Web 2.0 and enable creation and exchange of user-generated content." According to another definition, social media are "all activities, practices and behaviour within a community of people who go online to share information, knowledge and opinions" (Safko and Brake, 2009).

Social media are dynamic tools that facilitate online contacts (Golden, 2011). They involve a natural and general conversation among people about shared interests - they are about sharing information, and sometimes making a decision (Evans, 2010). Social media encompass several social networking sites and may change over time, with their participants and audience (consumers) constituting part of the creative process that generates content or conversations in real time (Evans, 2010).

Mayfield (2008) explains that social media are Internet or electronic media that facilitate participation, openness, conversation, community and connectedness among online users. The core feature of social media, as Trusov et al. (2009) explains, is that users can have individual profiles and personal images, and can share their thoughts, feelings, interests and links to related profiles (of their friends or professional fan pages). 
Social media facilitate exchange of information, digital audio, photos and films via email, chats, blogs, discussion forums (Mangold and Faulds, 2009).

Social media should be perceived as marketing tools and resources (Golden, 2011), as they provide marketers with a possibility of accessing valuable information, which has an impact on building relations and maintaining feedback with consumers (Evans, 2010). Social media marketing is a relatively lowbudget form of marketing that enables companies to have a direct contact with end users (Kaplan and Haenlein, 2010). Social media marketing is about passion, emotions and authenticity of expression towards brand. It builds relations between a consumer and brand, facilitates a dialogue and contributes to gaining respect for brand (Ramsunder, 2011).

Social networking sites focus on the human factor and provide a forum for users to express themselves creatively (Mayfield, 2008). Therefore, social networks give marketers insight into how people connect and engage with each other, and especially with the value of relationship building (The New Horizon Report, 2008). Thus, social media promote consumer to consumer communication and allow consumers and brands to engage with each other, thereby enabling connectedness (Mangold and Faulds, 2009).

Stelzner (2018) wrote that social media provided marketing possibilities to directly connect companies with their customers. In his report, Stelzner (2018) stated that 90\% of marketers considered social media as important for their activity, but only 38\% of marketers created data for measuring social media return on investment (ROI). Stelzner (2018) identified five popular social media platforms; Facebook, Linkedin, blogs, Twitter and YouTube.

Polańska (2011) indicates that the most widely used models of an enterprise's use of social media services for business purposes include: PR model, customer relationship building model, professional model and model of selling via a social media service (Table 1).

Table 1: Models of a company's use of social media services for business purposes according to Polańska (2011)

\begin{tabular}{|l|l|l|}
\hline No. & \multicolumn{1}{|c|}{ Model } & \multicolumn{1}{c|}{ Description } \\
\hline 1. & PR model & $\begin{array}{l}\text { A company account created for brand promotion is used to present } \\
\text { information about the company or its flagship product or advertisements } \\
\text { in the way-way communication mode. }\end{array}$ \\
\hline 2. & $\begin{array}{l}\text { Customer } \\
\text { relationship } \\
\text { building } \\
\text { model }\end{array}$ & $\begin{array}{l}\text { a) Personal profile -a personified company account. Its drawback is a } \\
\text { limited number of potential "friends" and the necessity of confirming } \\
\text { acquaintance with every new friend. } \\
\text { b) Company profile - there is no limit on the number of fans on Facebook } \\
\text { or followers on Twitter; the base of friends may grow without the need } \\
\text { for the webpage owner to confirm their access; this type of profile is } \\
\text { recommended not only to companies, but also to celebrities- the } \\
\text { moderator, who is responsible for running a company account, posts } \\
\text { updates about the company and its products and arranges discussions } \\
\text { with those interested; by setting up such a webpage it is possible to hold } \\
\text { competitions, votings, special campaigns, etc. and marketing and } \\
\text { promotion activities. } \\
\text { c) Customer-supporting company profile - a company account is set up } \\
\text { quickly, emergency support is provided to the customer; reported } \\
\text { problems are solved online by the company's specialists on duty as a } \\
\text { result of public two-way communication. }\end{array}$ \\
\hline 3. & $\begin{array}{l}\text { Professional } \\
\text { model }\end{array}$ & $\begin{array}{l}\text { An account devoted to a specific theme associated with the company's } \\
\text { activity or industry or the events in which the company is engaged, e.g. } \\
\text { through sponsoring or mentoring. On such a webpage, a company usually }\end{array}$ \\
\hline
\end{tabular}




\begin{tabular}{|l|l|l|}
\hline & & $\begin{array}{l}\text { displays its logo and promotes products or services closely connected } \\
\text { with the webpage's main theme. There is a two-way communication with } \\
\text { information recipients, and its aim is to engage Internet users as much as } \\
\text { possible. }\end{array}$ \\
\hline 4. & $\begin{array}{l}\text { Model of } \\
\text { selling via a } \\
\text { social media } \\
\text { service }\end{array}$ & $\begin{array}{l}\text { a) Internal type - involves the use of appropriate applications to enable } \\
\text { the purchase or sale of goods or services via a popular social media } \\
\text { service; } \\
\text { b) Autonomous type - involves creation of a dedicated social media } \\
\text { service to make group transactions possible a particular number of } \\
\text { people have to participate for a transaction to take place) in which } \\
\text { customers get significant discounts and sellers promote their products or } \\
\text { services; it is the so-called group buying, which is a very promising } \\
\text { solution on the e-commerce market in Poland. }\end{array}$ \\
\hline
\end{tabular}

On social media, virtual communities that are based on brands are most often located on the so-called fan pages, i.e. publicly available pages within a social networking site that enable users to interact actively (McCorkindale, 2010).On a fan page, both those running it (most often representatives of the brand) and fans can upload various text and graphical content, add comments, and use the like and share buttons. In this way, a brand community can make social media a place of meetings and the exchange of views and information. Exchange of views and discussions on brand through a fan page have, as a research by Liu and Lopez (2016) shows, a significant impact on fans' purchasing preferences (Grębosz-Krawczyk and Siuda, 2017 , p. 33).

A fan page is a profile set up in such categories as local company or place, corporate organisation or institution, brand or product, artist, band or a public figure, entertainment, a web page of a charity non-profit organisation or community. The administrator of a fan page can publish information that will be public and available to fans (Szymkowiak, 2014, p. 356).

In publications and reports, the term "fan page" refers to Facebook. For that reason, in this paper, the authors use a broader term, which is universal to every social media service - "company profile". It was defined in Business Dictionary (Web-3) as "Concise description which, among other items of information, includes (1) firm's history, (2) number and quality of its human, financial, and physical resources
(3) organizational and management structure, (4) past, current and anticipated performance, and (5) its reputation, and the standing of its goods or services." Meanwhile, Adows (Web-4) defines company profile through its elements: "It is part of a company's business plan that provides an overview of the company to potential customers and investors. It generally includes the following data: (1) the name of the founder(s) and the names and titles of the key members of the company, (2) the official name of the company, its address, its telephone number, and its email address, (3) the overall business activities of the company, (3) the company's overall strategy, including its purpose and mission statement, (4) the structure of the company: whether it's public, private, or a partnership, (5) who serves on the board of directors, if there is a board, (6) the numbers and types of employees or independent contractors in the company, (7) the basic financial data related to the company, including its yearly revenue, profits, and major assets, (8) places where the company does business, (9) the operations and mission of the company, including what sets it apart from other companies, (10) the way in which the company informs shareholders about its financial picture, (11) the achievements that the company has made recently, (12) the short- and longer-term goals of the company."

It should be stressed that the main aim of a company's activities on the web should not be to maximise user activity statistics, but to achieve business outcomes and 
complement the company's business model. Therefore, while building a strategy for social media presence and calculating ROI, it is worth looking at a broader strategy for customer relationship management, the company's business objectives, brand strategy and the company's openness to innovation. Although the interest in social media among Polish companies is growing and they set commercial objectives for their presence on the web, in 2012 only $4 \%$ of surveyed companies measured ROI and only $4 \%$ estimated the value of their brand. Research shows the most popular indicators are the number of users interacting with brand (56\%) and frequency of page visits (52\%) (Biznes społecznościowy..., 2012, p. 18).

Meanwhile, a 2012 report on the study entitled Polskie firmy $w$ mediach społecznościowych (Polish companies on social media) revealed that enterprises only concentrated on promoting products and services and on image-related activities. Moreover, it was found that although these companies are already present on social media, they treat them as an additional marketing channel rather than a phenomenon that makes it possible to create completely new ways of operating and business models.

With the average time during which a consumer is able to concentrate on content decreasing from 12 seconds in 2000 to 8 seconds in 2013, modern marketers face a difficult task. As it is more and more difficult to present brand information in less and less time, marketers should concentrate on designing a WOW factor that makes a given brand stand out on the market, and on arranging conversations about brand within consumer communities. This is because creating favourable conditions for conversations about brand can help win loyal advocates (Kotleri et al., 2017).

\section{Characteristics of the Generation $Z$}

People aged 15 to 24 (Jędrzejczyk and Konieczna-Kucharska, 2017), who represent the so-called generation $\mathrm{Z}$, are prevalent among social media users. There is no agreement in the literature on the dates that can be used to identify the different generations. One of the most popular classifications is division based on a cohort's year of birth: the Silent Generation (1925-1945), the Baby Boomers (1946-1960), Generation X (1961-1981) and Generation Y/Millennials (born after 1981) (Brosdahl, Carpenter, 2011). However, there is another identified cohort - generation Z - and its representatives are currently entering the labour market (Skibiński, Sipa and GorzeńMitka, 2016). With no agreement on and exact specification of the end year of birth of the representatives of generation $Y$, the literature does not clearly specify the start year of birth of representatives of the subsequent generation, i.e. Z. For the purpose of the research, the authors, following a few other researchers, adopted the year 1995 (and later years) as the year of birth of people from generation $\mathrm{Z}$ (Bartlett, 2004), (Dalton, 2003), (Lafayette, 2011). The representatives of generation $Z$ differ significantly from the representatives of the previous generations. It is due to the conditions in which they were brought up. They were born into a digital world at a time of huge social, economic and political changes. They do not know a reality without the Internet or smartphone - they have been using such devices since they were very young, which earned them the nickname "digital natives". Often, the virtual world is more important to them than the real one in which they live. There are no boundaries for representatives of generation $\mathrm{Z}$ - change of the place of residence or change of the type and place of work is a natural part of life to them (Sladek and Grabinger, 2014; Web-1). When characterising representatives of generation $\mathrm{Z}$ as employees, it should be highlighted that they are able to multi-task, passion matters to them a lot, and they are willing to work in teams provided that the teamwork takes place in virtual settings. What will be their asset when performing certain types of activities will make them quickly bored with other activities and quit the job (Web-2).The most important characteristics of the representatives of generation $\mathrm{Z}$ include: financially conscious, 
global-minded, lacking work experience, tech-savvy (Sladek, Grabinger, 2014). Moreover, representatives of generation $\mathrm{Z}$ are responsible, loyal, thoughtful, compassionate, open minded, determined (Seemiller, Grace, 2013) (Table 1).

\section{Research Objectives and Methodology}

The study was conducted using the CAWI technique - the survey questionnaire was made available on the platform Webankieta.pl. The survey was conducted at the end of November and beginning of December 2018 among students of the Faculty of Management at the Czestochowa University of Technology. The participants completed the survey questionnaires by themselves. A total of 264 students participated in the survey, and responses of 223 students were qualified for the analysis. There is no agreement in the literature regarding the year of birth of representatives of generation $\mathrm{Z}$. The most often cited date is the year 1995, which the authors of the paper assumed to be the cutoff year in their study. The basic qualification criterion was a respondent's date of birth - 1995 or later.

In this paper, selected questions from the questionnaire have been analysed to find answers to the following research questions:

1. How do representatives of generation $\mathrm{Z}$ evaluate the usefulness of a company profile created by an enterprise to shape opinions about a service/product, company?

2. Which of the activities undertaken by enterprises on social media had an impact on purchasing decisions of representatives of generation $\mathrm{Z}$ ?

The aim of the paper is to find out how representatives of generation $\mathrm{Z}$ assess the creation of a company profile by an enterprise on social media, and to indicate the actions taken by an enterprise on its company profile on social media that had the biggest impact on representatives of generation Z's decision to make a purchase.

The authors formulated the following research hypotheses:
H1: A company profile of an enterprise is a significant factor in shaping opinions of generation Z's representative about a service/product/company.

H2: Gender of a representative of generation $\mathrm{Z}$ has an impact on their assessment of the usefulness of an enterprise's company profile as a factor in shaping opinions about a service/product/company.

H3: Place of residence of a representative of generation $\mathrm{Z}$ has an impact on their assessment of the usefulness of an enterprise's company profile as a factor in shaping generation Z's opinions about a service/product/company.

H4: Actions undertaken by an enterprise on its social media company profile have an impact on whether representatives of generation $\mathrm{Z}$ decide to make a purchase.

H5: Actions undertaken by an enterprise on its social media company profile have a different impact depending on gender on whether representatives of generation $\mathrm{Z}$ decide to make a purchase.

H6: Actions undertaken by an enterprise on its social media company profile have a different impact depending on place of residence on whether representatives of generation $\mathrm{Z}$ decide to make a purchase.

In the research, qualitative characteristics (nominal and rank scales) were assessed. The specificity of analysing such data is the use of appropriate statistic tools for comparisons. In order to determine the strength of the relationship between variables measured on a rank scale, vectors of Spearman's rank correlation coefficients were calculated. Non-parametric MannaWhitney U test was used to verify whether gender has a significant impact on the differences between variables on a rank scale. For variables measured on a nominal scale, hypotheses stating that two qualitative characteristics in a population are independent were verified: H0: characteristics $\mathrm{X}$ and $\mathrm{Y}$ are independent with regard to alternative hypothesis: H1: characteristics $\mathrm{X}$ and $\mathrm{Y}$ are dependent. 
The "tool" most often used for that purpose is Pearson's chi-squared test. It consists in comparing observed frequencies with expected frequencies assuming null hypothesis (stating that there is no relationship between these two variables). Chi-squared statistic tests whether two variables are related to each other. However, apart from determining whether a relationship exists between variables, the authors also examined how strong this relationship is. The value of Pearson's chisquared could not be used as a measure of relationship strength, hence Kendall's tau-b and tau-c coefficients and Spearman's rank correlation coefficients were used. For all the analyses, the level of significance of 0.05 was assumed. All the analyses were conducted using software Statistica v.12.

\section{Findings}

Creation of a company profile on social media by an enterprise was considered by most respondents representing generation $\mathrm{Z}(75.78 \%)$ as an important source of information about a company and its offer (Table 2). Thus, hypothesis $\mathrm{H} 1$ has been confirmed.

Table 2: The idea to create a company profile as a factor in shaping opinions about a service/product/company as assessed by representatives of generation $Z$

\begin{tabular}{|c|c|c|c|}
\hline $\begin{array}{l}\text { How do you assess the idea to create a company profile as a } \\
\text { factor in shaping opinions about a service/product/company? }\end{array}$ & $\begin{array}{c}\text { Gender } \\
\text { male }\end{array}$ & $\begin{array}{l}\text { Gender } \\
\text { female }\end{array}$ & In total \\
\hline $\begin{array}{l}\text { A hardly important source of information about a company and its } \\
\text { offer }\end{array}$ & 1 & 5 & 6 \\
\hline$\%$ of the total & $0.45 \%$ & $2.24 \%$ & $2.69 \%$ \\
\hline An average source of information about a company and its offer & 10 & 38 & 48 \\
\hline$\%$ of the total & $4.48 \%$ & $\begin{array}{c}17.04 \\
\%\end{array}$ & $21.52 \%$ \\
\hline A significant source of information about a company and its offer & 30 & 139 & 169 \\
\hline$\%$ of the total & $\begin{array}{c}13.45 \\
\%\end{array}$ & $\begin{array}{c}62.33 \\
\%\end{array}$ & $75.78 \%$ \\
\hline In total & 41 & 182 & 223 \\
\hline$\%$ of the total & $18.39 \%$ & $81.61 \%$ & $\begin{array}{c}100.00 \\
\%\end{array}$ \\
\hline
\end{tabular}

Only $2.69 \%$ of the respondents assessed an enterprise's idea to create a company profile on social media as a hardly important source of information about the company and its offer. In the next step of the research, it was examined whether gender of the representative of generation $\mathrm{Z}$ had an impact on their assessment of the usefulness of an enterprise's company profile as a factor in shaping opinions about a service/product/company (Table 3). 
Table 3: Results of a static test to find out the answer to the question: Does the respondent's gender have an impact on how they assess the idea to create a company profile as a factor in shaping opinions about a service/product, company?

\begin{tabular}{|l|c|c|c|}
\hline & Chi - square & df & P \\
\hline Pearson's Chi^2 & 0.2487596 & $\mathrm{df}=2$ & $\mathrm{p}=0.88304$ \\
\hline Kendall's tau-b and tau-c & $\mathrm{b}=0.0270839$ & $\mathrm{c}=0.0182590$ & \\
\hline Spearman's rank R & 0.0274034 & $\mathrm{t}=0.40753$ & $\mathrm{p}=0.68401$ \\
\hline
\end{tabular}

The static test has not given a basis for stating significant relationships between the variables How do you assess the idea to create a company profile as a factor in shaping opinions about a service/product/company? and the respondent's gender $(\mathrm{p}=0.83)$. Therefore, hypothesis $\mathrm{H} 2$ has not been confirmed. During the next stage of the research, the authors focused their attention on finding the answer to the question: Does the place of residence of the representative of generation $\mathrm{Z}$ have an impact on their assessment of the usefulness of an enterprise's company profile as a factor in shaping generation Z's opinions about a service/product/company (Table 4).

Table 4: Results of a static test to find out the answer to the question: Does the respondent's place of residence have an impact on how they assess the idea to create a company profile as a factor in shaping opinions about a service/product/company?

\begin{tabular}{|l|c|}
\hline $\mathrm{N}$ of valid ones & 223 \\
\hline $\mathrm{R}$ Spearman & 0.01 \\
\hline $\mathrm{T}(\mathrm{N}-2)$ & 0.08 \\
\hline $\mathrm{P}$ & 0.94 \\
\hline
\end{tabular}

Spearman's rank-order correlation (Vector) BD eliminated in pairs. Marked correlation coefficients are significant with $p<.05000$.

No statistically significant correlations have been found between the analysed variables $(p>0.05)$. The place of residence has not been significantly correlated with the variable How do you assess the idea to create a company profile as a factor in shaping opinions about a service/product/company? Hypothesis H3 has not been confirmed.
In the subsequent step of the research, the authors made an attempt to find out whether, and if so, which activities undertaken by an enterprise on its company profile on social media had an impact on whether representatives of generation $\mathrm{Z}$ decided to make a purchase. The indicators of structure for the individual actions are presented in tables 5, 6 and 7.

Table 5: Indicator of structure for actions 1 - 4

\begin{tabular}{|c|c|c|c|c|}
\hline \multirow{5}{*}{ Classes } & \multicolumn{4}{|c|}{ Actions } \\
\hline & 1 & 2 & 3 & 4 \\
\hline & $\begin{array}{c}\text { Publishing } \\
\text { information } \\
\text { about what is } \\
\text { new in the offer }\end{array}$ & $\begin{array}{l}\text { Presenting an } \\
\text { application of a } \\
\text { specific } \\
\text { product/service }\end{array}$ & $\begin{array}{c}\text { Publishing } \\
\text { information } \\
\text { about } \\
\text { promotion }\end{array}$ & $\begin{array}{c}\text { Presenting a test } \\
\text { carried out by an } \\
\text { expert }\end{array}$ \\
\hline & \multicolumn{4}{|c|}{ Table of numbers } \\
\hline & Number & Number & Numbe & Number \\
\hline
\end{tabular}




\begin{tabular}{|c|c|c|c|c|c|c|c|c|}
\hline & & & & & $r$ & & & \\
\hline $\begin{array}{c}\text { Definitely } \\
\text { had no } \\
\text { impact }\end{array}$ & 10 & 4.48430 & 11 & 4.93274 & 5 & $\begin{array}{c}2.2421 \\
5\end{array}$ & 16 & 7.17489 \\
\hline $\begin{array}{c}\text { Rather } \\
\text { had no } \\
\text { impact }\end{array}$ & 36 & $\begin{array}{c}16.1435 \\
0\end{array}$ & 36 & $\begin{array}{c}16.1435 \\
0\end{array}$ & 22 & $\begin{array}{c}9.8654 \\
7\end{array}$ & 50 & 22.42152 \\
\hline $\begin{array}{c}\text { I have no } \\
\text { opinion }\end{array}$ & 25 & $\begin{array}{c}11.2107 \\
6\end{array}$ & 23 & $\begin{array}{c}10.3139 \\
0\end{array}$ & 16 & $\begin{array}{c}7.1748 \\
9\end{array}$ & 51 & 22.86996 \\
\hline $\begin{array}{c}\text { Rather } \\
\text { had an } \\
\text { impact }\end{array}$ & 120 & $\begin{array}{c}53.8116 \\
6\end{array}$ & 118 & $\begin{array}{c}52.9148 \\
0\end{array}$ & 110 & $\begin{array}{c}49.327 \\
35\end{array}$ & 82 & 36.77130 \\
\hline $\begin{array}{c}\text { Definitely } \\
\text { had an } \\
\text { impact }\end{array}$ & 32 & $\begin{array}{c}14.3497 \\
8\end{array}$ & 35 & $\begin{array}{c}15.6950 \\
7\end{array}$ & 70 & $\begin{array}{c}31.390 \\
13\end{array}$ & 24 & 10.76233 \\
\hline $\begin{array}{c}\text { No } \\
\text { answer }\end{array}$ & 0 & 0.00000 & 0 & 0.00000 & 0 & $\begin{array}{c}0.0000 \\
0\end{array}$ & 0 & 0.00000 \\
\hline
\end{tabular}

Table 6: Indicator of structure for actions 5 - 8

\begin{tabular}{|c|c|c|c|c|c|c|c|c|}
\hline \multirow{5}{*}{ Classes } & \multicolumn{8}{|c|}{ Actions } \\
\hline & \multicolumn{2}{|r|}{5} & \multicolumn{2}{|c|}{6} & \multicolumn{2}{|c|}{7} & \multicolumn{2}{|c|}{8} \\
\hline & \multicolumn{2}{|c|}{$\begin{array}{c}\text { Recommendati } \\
\text { on from a } \\
\text { known person }\end{array}$} & \multicolumn{2}{|c|}{$\begin{array}{l}\text { Participation in a } \\
\text { competition }\end{array}$} & \multicolumn{2}{|c|}{$\begin{array}{c}\text { Receipt of a } \\
\text { discount coupon }\end{array}$} & \multicolumn{2}{|c|}{$\begin{array}{l}\text { Making the wall } \\
\text { available for } \\
\text { asking questions }\end{array}$} \\
\hline & \multicolumn{8}{|c|}{ Table of numbers } \\
\hline & $\begin{array}{l}\text { Num } \\
\text { ber }\end{array}$ & $\begin{array}{l}\text { Percenta } \\
\text { ge }\end{array}$ & $\begin{array}{l}\text { Numb } \\
\text { er }\end{array}$ & $\begin{array}{l}\text { Percenta } \\
\text { ge }\end{array}$ & $\begin{array}{l}\text { Numb } \\
\text { er }\end{array}$ & $\begin{array}{l}\text { Percenta } \\
\text { ge }\end{array}$ & $\begin{array}{l}\text { Numb } \\
\text { er }\end{array}$ & $\begin{array}{l}\text { Percenta } \\
\text { ge }\end{array}$ \\
\hline $\begin{array}{l}\text { Definitely } \\
\text { had no } \\
\text { impact }\end{array}$ & 36 & $\begin{array}{c}16.1435 \\
0\end{array}$ & 47 & $\begin{array}{c}21.0762 \\
3\end{array}$ & 22 & 9.86547 & 46 & $\begin{array}{c}20.6278 \\
0\end{array}$ \\
\hline $\begin{array}{l}\text { Rather } \\
\text { had no } \\
\text { impact }\end{array}$ & 67 & $\begin{array}{c}30.0448 \\
4\end{array}$ & 69 & $\begin{array}{c}30.9417 \\
0\end{array}$ & 16 & 7.17489 & 64 & $\begin{array}{c}28.6995 \\
5\end{array}$ \\
\hline $\begin{array}{l}\text { I have no } \\
\text { opinion }\end{array}$ & 42 & $\begin{array}{c}18.8340 \\
8 \\
\end{array}$ & 43 & $\begin{array}{c}19.2825 \\
1\end{array}$ & 12 & 5.38117 & 60 & $\begin{array}{c}26.9058 \\
3 \\
\end{array}$ \\
\hline $\begin{array}{l}\text { Rather } \\
\text { had an } \\
\text { impact }\end{array}$ & 58 & $\begin{array}{c}26.0089 \\
7\end{array}$ & 50 & $\begin{array}{c}22.4215 \\
2\end{array}$ & 108 & $\begin{array}{c}48.4304 \\
9\end{array}$ & 43 & $\begin{array}{c}19.2825 \\
1\end{array}$ \\
\hline $\begin{array}{l}\text { Definitely } \\
\text { had an } \\
\text { impact }\end{array}$ & 20 & 8.96861 & 14 & 6.27803 & 65 & $\begin{array}{c}29.1479 \\
8\end{array}$ & 10 & 4.48430 \\
\hline $\begin{array}{l}\text { No } \\
\text { answer }\end{array}$ & 0 & 0.00000 & 0 & 0.00000 & 0 & 0.00000 & 0 & 0.00000 \\
\hline
\end{tabular}


Table 7: Indicator of structure for actions 9 - 11

\begin{tabular}{|c|c|c|c|c|c|c|}
\hline \multirow{5}{*}{ Classes } & \multicolumn{6}{|c|}{ Actions } \\
\hline & \multicolumn{2}{|c|}{9} & \multicolumn{2}{|c|}{10} & \multicolumn{2}{|c|}{11} \\
\hline & \multicolumn{2}{|c|}{$\begin{array}{l}\text { Positive actions by a } \\
\text { brand/company that } \\
\text { you have liked in } \\
\text { particular }\end{array}$} & \multicolumn{2}{|c|}{$\begin{array}{l}\text { Social responsibility, } \\
\text { social campaigns }\end{array}$} & \multicolumn{2}{|c|}{ Other, specify } \\
\hline & \multicolumn{6}{|c|}{ Table of numbers } \\
\hline & Number & Percentage & Number & Percentage & Number & Percentage \\
\hline $\begin{array}{l}\text { Definitely } \\
\text { had no } \\
\text { impact }\end{array}$ & 18 & 8.07175 & 20 & 8.96861 & 65 & 29.14798 \\
\hline $\begin{array}{l}\text { Rather had } \\
\text { no impact }\end{array}$ & 40 & 17.93722 & 40 & 17.93722 & 12 & 5.38117 \\
\hline $\begin{array}{l}\text { I have no } \\
\text { opinion }\end{array}$ & 48 & 21.52466 & 71 & 31.83857 & 119 & 53.36323 \\
\hline $\begin{array}{l}\text { Rather had } \\
\text { an impact }\end{array}$ & 83 & 37.21973 & 67 & 30.04484 & 14 & 6.27803 \\
\hline $\begin{array}{l}\text { Definitely } \\
\text { had an } \\
\text { impact }\end{array}$ & 34 & 15.24664 & 25 & 11.21076 & 13 & 5.82960 \\
\hline No answer & 0 & 0.00000 & 0 & 0.00000 & 0 & 0.00000 \\
\hline
\end{tabular}

Based on analysis of the data contained in tables 5, 6 and 7, it can be stated that actions undertaken by entrepreneurs on their company profiles have an impact on purchasing decisions of representatives of generation Z. Thus, hypothesis $\mathrm{H} 4$ has been confirmed. Actions with a significant impact on purchasing decisions of representatives of generation $\mathrm{Z}$ include: action No 3 Publication of information about promotion (31.39\%) and action No 7 Receipt of a discount coupon (29.15\%). Actions with less impact on purchasing decisions of representatives of generation $\mathrm{Z}$ include: action No 2 Presenting an application of a specific product/service (15.7\%), action No 9 Positive actions of a brand/company that you have liked in particular (15.25\%) and action No 1 Publishing information about what is new in the offer (14.35\%).

Next, the authors examined the impact of actions undertaken by companies via social media on the decision to make a purchase depending on the respondent's gender (Table 8).

Table 8: Impact of actions undertaken by companies via social media on the decision to make a purchase depending on the respondent's gender

\begin{tabular}{|c|l|c|c|c|c|c|}
\hline No. & $\begin{array}{c}\text { Which of the below-listed actions } \\
\text { undertaken by companies via social media } \\
\text { have ever had an impact on your decision to } \\
\text { make a purchase? }\end{array}$ & $\begin{array}{c}\text { Sum of } \\
\text { ranks } \\
\text { Male }\end{array}$ & $\begin{array}{c}\text { Sum of } \\
\text { ranks } \\
\text { Female }\end{array}$ & $\mathbf{U}$ & $\mathbf{Z}$ & $\mathbf{p}$ \\
\hline 1. & Publishing information about what is new & 3681.50 & 21294.50 & 2820.50 & $-\mathbf{2 . 4 4}$ & $\mathbf{0 . 0 1}$ \\
\hline 2 & $\begin{array}{l}\text { Presenting an application of a particular } \\
\text { product/service }\end{array}$ & 4286.50 & 20689.50 & 3425.50 & -0.82 & 0.41 \\
\hline 3 & Publishing information about promotion & 3397.00 & 21579.00 & 2536.00 & $\mathbf{- 3 . 2 0}$ & $\mathbf{0 . 0 0 1}$ \\
\hline
\end{tabular}




\begin{tabular}{|c|l|c|c|c|c|c|}
\hline 4 & Presenting a test carried out by an expert & 4514.00 & 20462.00 & 3653.00 & -0.21 & 0.84 \\
\hline 5 & Recommendation from a known person & 4207.00 & 20769.00 & 3346.00 & -1.03 & 0.30 \\
\hline 6. & Participation in a competition & 4413.00 & 20563.00 & 3552.00 & -0.48 & 0.63 \\
\hline 7. & Receipt of a discount coupon & 3716.00 & 21260.00 & 2855.00 & $-\mathbf{2 . 3 5}$ & $\mathbf{0 . 0 2}$ \\
\hline 8. & Making the wall available for asking questions & 4554.50 & 20421.50 & 3693.50 & -0.10 & 0.92 \\
\hline 9. & $\begin{array}{l}\text { Positive actions by a brand/company that you } \\
\text { have liked in particular }\end{array}$ & 4554.00 & 20422.00 & 3693.00 & -0.10 & 0.92 \\
\hline 10. & Social responsibility, social campaigns & 4307.00 & 20669.00 & 3446.00 & -0.76 & 0.45 \\
\hline 11. & Other, specify & 5079.00 & 19897.00 & 3244.00 & 1.30 & 0.19 \\
\hline
\end{tabular}

Mann-Whitney $U$ test (adjusted for continuity) (Vector) for the variable: Gender. Marked results are significant with $p<0.05000$.

Analysis has shown that gender had a significant impact on the differences in the analysed variables in three cases: action No 1 Publishing information about what is new $(\mathrm{p}=0.01)$, action No 3 Publishing information about promotion $(\mathrm{p}=0.001)$ and action No 7 Receipt of discount coupon $(\mathrm{p}=0.02)$. In the case of these three variables, the actions had a significantly stronger impact on purchasing decisions of females relative to males, which is also confirmed by graphical interpretations (Figures 1, 2 and 3).

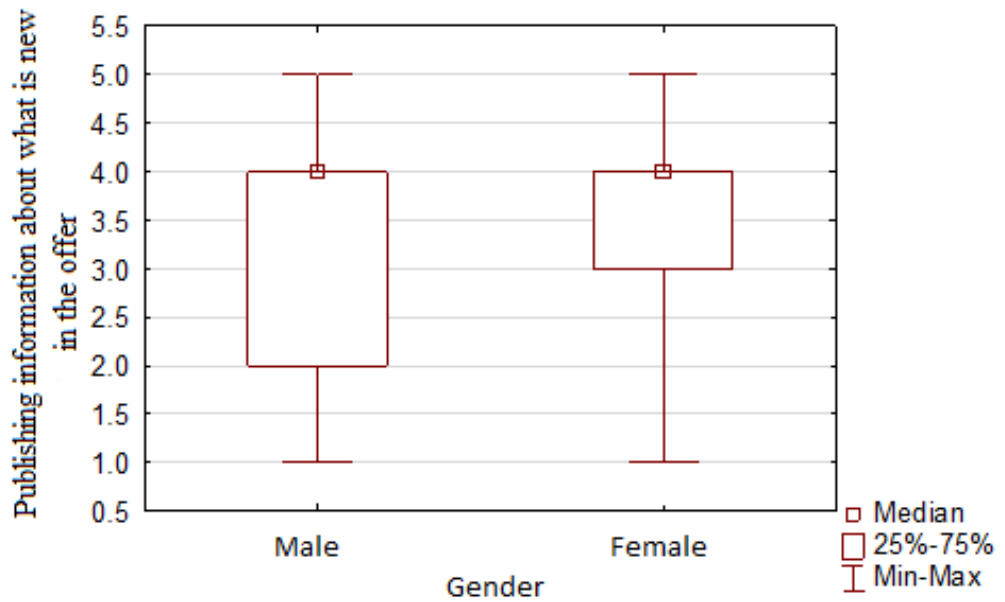

Figure 1: Impact of publishing information about what is new on representatives of generation $\mathrm{Z}$ depending on gender 


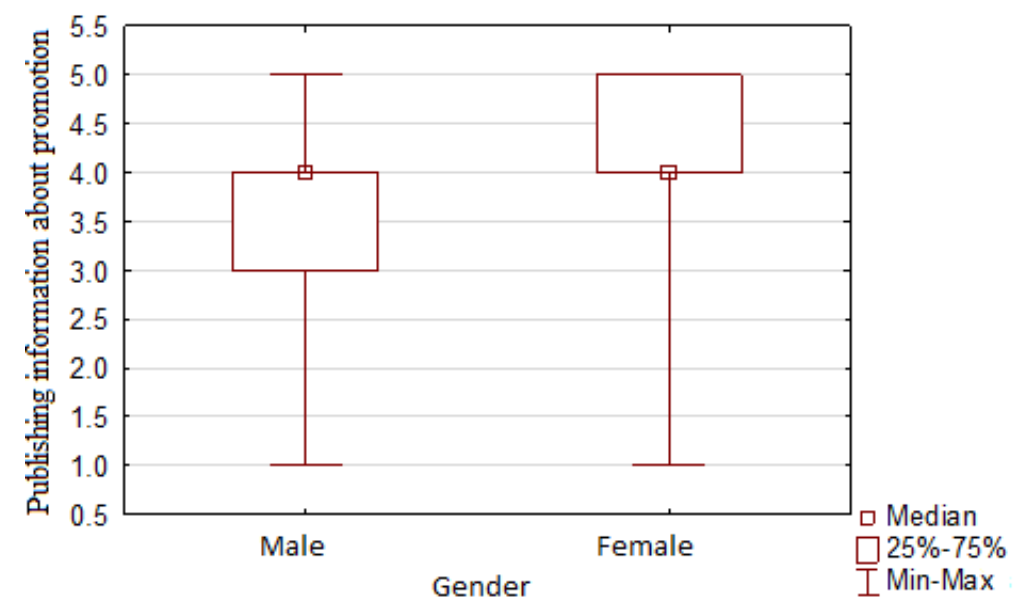

Figure 2: Impact of published information about promotion on representatives of generation $\mathrm{Z}$ depending on gender

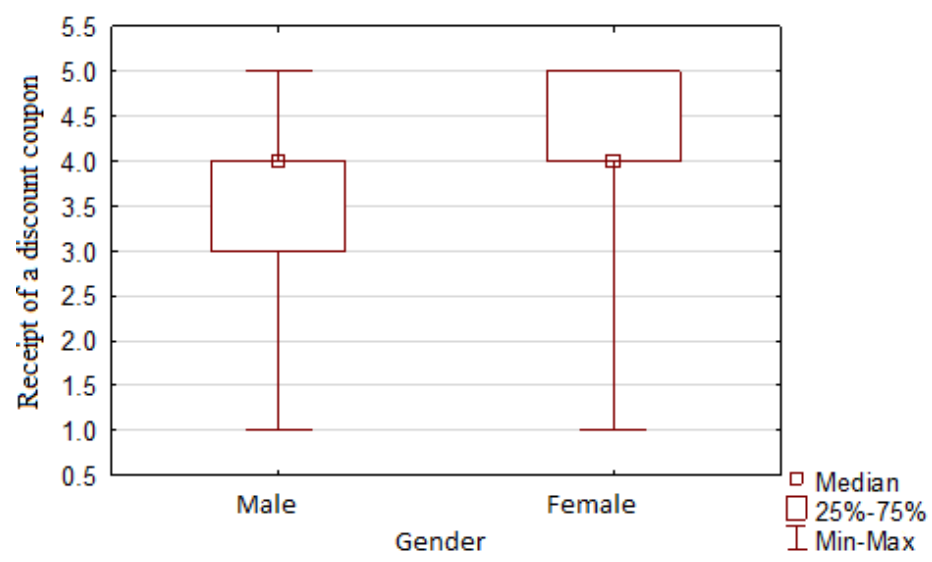

Figure 3: Impact of receipt of a discount coupon on representatives of generation $\mathrm{Z}$ depending on gender

The discussion above has allowed hypothesis H5 to be partially confirmed. Three of the actions undertaken by an enterprise on its social media company profile have a different impact depending on gender on purchasing decisions of representatives of generation $\mathrm{Z}$.
Next, the authors examined the impact of actions undertaken by an enterprise on its social media company profile on the decision of representatives of generation $\mathrm{Z}$ to make a purchase depending on the place of residence (Table 9). 
Table 9: Impact of actions undertaken by companies via social media on the decision to make a purchase depending on the respondent's place of residence

\begin{tabular}{|l|c|c|c|c|}
\hline $\begin{array}{l}\text { Which of the below-listed actions undertaken by } \\
\text { companies via social media have ever had an impact on } \\
\text { you while making a purchasing decision? }\end{array}$ & $\begin{array}{c}\text { N of } \\
\text { valid } \\
\text { ones }\end{array}$ & $\begin{array}{c}\text { R } \\
\text { Spear- } \\
\text { man }\end{array}$ & t (N-2) & p \\
\hline Publishing information about what is new & 223 & -0.10 & -1.50 & 0.13 \\
\hline Presenting an application of a particular product/service & 223 & -0.06 & -0.89 & 0.38 \\
\hline Publishing information about promotion & 223 & 0.02 & 0.36 & 0.72 \\
\hline Presenting a test carried out by an expert & 223 & -0.01 & -0.11 & 0.91 \\
\hline Recommendation from a known person & 223 & -0.11 & -1.61 & 0.11 \\
\hline Participation in a competition & 223 & -0.08 & -1.19 & 0.23 \\
\hline Receipt of a discount coupon & 223 & -0.08 & -1.20 & 0.23 \\
\hline Making the wall available for asking questions & 223 & -0.06 & -0.95 & 0.34 \\
\hline $\begin{array}{l}\text { Positive actions by a brand/company that you have liked in } \\
\text { particular }\end{array}$ & 223 & -0.01 & -0.13 & 0.90 \\
\hline Social responsibility, social campaigns & 223 & 0.00 & 0.03 & 0.98 \\
\hline Other, specify & 223 & 0.01 & 0.13 & 0.90 \\
\hline $\begin{array}{l}\text { Spearman's rank-order correlation (Vector) BD eliminated in pairs. Marked correlation coefficients are } \\
\text { significant with } p \text { <.05000 }\end{array}$ & & & \\
\hline
\end{tabular}

No statistically significant correlations have been found between the analysed variables $(p>0.05)$. The place of residence has not been significantly correlated with dependent variables - actions taken by an enterprise on its company profile on social media in order to impact representatives of generation $\mathrm{Z}$ in their decisions to make a purchase. Hypothesis $\mathrm{H} 6$ has not been confirmed.

\section{Conclusions}

In present-day world, an entrepreneur, if they want to, can, at relatively low costs, reach and establish a contact with their existing and potential customers via social media. This form of communication enables building long-term relations, especially with representatives of generation $\mathrm{Z}$, for whom the virtual world is often their primary world. Building a company profile in order to achieve outcomes requires from an entrepreneur extensive knowledge, not only marketing and technical one, but also knowledge of the target group. The research conducted by the authors allows them to state that:
- Most surveyed representatives of generation $\mathrm{Z}$ consider a company profile to be a valuable source of information about a company and its offer.

- There are no relationships between gender and place of residence and assessment of the usefulness of a company profile,

- Actions taken by entrepreneurs on their company profiles impact purchasing decisions of representatives of generation $\mathrm{Z}$. Actions with the biggest impact on their purchasing decisions include: publishing information about promotion and receipt of a discount coupon. Actions with less impact include: presenting an application of a given product/service, positive actions by a brand/company that respondents liked in particular and publishing information about what is new in the company's offer.

- Actions that had a significantly higher impact on purchasing decisions of women representing generation $\mathrm{Z}$ are: publishing information about what is new in the company's offer, publishing 
information about promotion and receipt of a discount coupon.

- A respondent's place of residence has not been significantly correlated with actions taken by an enterprise on a company profile.

The findings have confirmed significant differences in the decision-making process between men and women. This was also confirmed by the research presented by Kotler. Before purchasing a certain product/service, women take a lot of time to obtain as much information as possible and then to discuss it with those close to them, whereas men limit information search to the necessary minimum and purchase what they need in the shortest time (Kotler et al. 2017).

It should be stressed that the study was not conducted on a representative sample, hence the conclusions above refer to the population that was examined, and generalising them to the whole population would require further research.

Social media are still a very popular tool for communication with customers and establishing new business contacts. At present, this tool is becoming obligatory, as the audience simply expect their favourite brand to be present on social media. Naturally, in order to participate in online life and not fail, one has to set certain limits, develop solutions to be used in a crisis situation, and continuously learn in order to keep up with changes, which are the only certain thing in this environment. It is also worth following success stories of companies, organisations and public institutions.

Representatives of generation $\mathrm{Z}$ are people who like changes, so they do not get attached to jobs or brands. It is brand that should strive to attract their interest. In order to be able to monitor the changing tastes and expectations of the representatives of this generation, it seems necessary to conduct further representative studies. This is, however, very difficult due to the fact that generation $\mathrm{Z}$ is just entering the labour market. The attempt to characterize the resulting cohort is based more on predictions than on final conclusions. Research on the Polish cohort $\mathrm{Z}$ is additionally hampered by the fact that it is deeply divided in economic and cultural terms. This is due to the fact that it is the first generation after the political system transformation in Poland, which took place in 1989. Currently, two groups can be distinguished in generation Z: a group of people taking advantage of the achievements of their parents, with very good education and significant financial resources, and a group of people who do not have such resources. These two different groups will differ in their perception and assessment of occurring phenomena. The most effective ways to reach the representatives of generation $\mathrm{Z}$ are to: 1. Intuitively deliver on their constantly evolving needs, 2. Make them part of the solution and 3. Demonstrate respect and loyalty before asking for it (Web-5). The authors of the study point to the necessity to conduct further research focusing on continuous identification of the changing needs of representatives of generation $\mathrm{Z}$ and on identification and creation of such solutions by enterprises that will show their loyalty to the representatives of generation $\mathrm{Z}$ and at the same time enable them to choose what, how, where and when they want to buy.

\section{References}

1. Bartlett, M. (2004). 'Analyst: understanding what shapes generation can help the . . . ,' Credit Union Journal, No. 8(21), 14-17.

2. 'Biznes społecznościowy - nowa era w komunikacji biznesowej,' raport based on „Polskie firmy na Facebooku - portale społecznościowe w komunikacji marketingowej polskich przedsiębiorstw" (2012). [online]. Deloitte. [Accessed February 01, 2019]. Available: https://marketingowe.files.wordpress.com /2013/10/raport-biznes-

spolecznosciowy.pdf.

3. Brosdahl, D.J. and Carpenter, J.M. (2011). 'Shopping orientations of US males: a generational cohort comparison,' Journal 
of Retailing and Consumer Services, Vol. 18 No. 6, 548-554.

4. Dalton, P. (2003). 'Managing the generation,' $A B A$ Washington News, No. 11(19).

5. Evans, L. (2010). Social Media Marketing: Strategies for Engaging in Facebook, Twitter\& Other Social Media. Que.

6. Evans, D. and McKee, J. (2010). Social Media Marketing: The Next Generation of Business Engagement. Indiana: John Wiley and Sons.

7. Grębosz-Krawczyk, M. and Siuda, D. (2017). 'Typy uczestników wirtualnych społeczności marek,' Studia Ekonomiczne. Zeszyty Naukowe Uniwersytetu Ekonomicznego w Katowicach, No. 328, 3039.

8. Golden, M. (2011). Social Media Strategies for Professionals and Their Firms: The Guide to Establishing Credibility and Accelerating Relationships. New Jersey: John Wiley and Sons.

9. Jędrzejczyk, W. and KoniecznaKucharska, M. (2017). 'Użyteczność mediów społecznościowych z perspektywy podmiotów gospodarczych', [in:] Techniki i technologie wspomagające funkcjonowanie przedsiębiorstw, Kiełtyka, L. and Sokołowski, A. (eds.), Wyd. PCz, Częstochowa, 63-75.

10. Kaplan, A.M. and Haenlein, M. (2010). 'Users of the world, unite! The challenges and opportunities of Social Media,' Bussiness Horizon, 53(1), 59-68.

11. Kotler, P., Kartajaya, H. and Setiawan, I. (2017). Marketing 4.0, Era cyfrowa, MT biznes.

12. Lafayette, J. (2011). 'Marketers targeting generation of Millennials,' Broadcasting \& Cable, No. 28.

13. Liu, Y. and Lopez, R.A. (2016), 'The Impact of Social Media Conversations on
Consumer Brand Choices,' Marketing Letters, Vol. 27, No 1, 1-13.

14. Mangold, W.G. and Faulds, D.J. (2009). 'Social media: The new hybrid element of the promotion mix,' Business Horizons, 52, 357-365.

15. Mayfield, T.D. (2008). 'What is social media?' [online]. iCrossing. [Accessed February 03, 2019]. Available: https://www.icrossing.com/uk/sites/defa ult/files_uk/insight_pdf_files/What $\% 20$ is $\%$ 20 Social\%20Media_iCrossing_ebook.pdf.

16. McCorkindale, T. (2010). 'Can You See the Writing My Wall? A Content Analysis of the Fortune 50's Facebook Social Networking Sites,' Public Relation Journal, Vol. 4, 1-13.

17. Passios, T. and Pleasant, B. (2012). 'A realistic look at social media and the contact center,' Customer Interaction Solutions, 01/2012, 1-12.

18. Polańska, K. (2011). 'Biznesowy charakter mediów społecznośiowych,' Zeszyty naukowe Uniwersytetu Szczecińskiego, No. 656, Studia Informatica No. 28, 73-87.

19. Ramsunder, M. (2011). 'The Impact of Social Media Marketing on Purchase Decisions in the Tyre Industry'. [online]. [Accessed February 03, 2019]. Available: https://core.ac.uk/download/pdf/145053 328.pdf.

20. Safko, L. and Brake, D.K. (2009). The Social Media Bible: Tactics, Tools and Strategies for Bussiness Success. John Willey \& Sons Inc., New Jersey.

21. Szymkowiak A. (2014). 'Verification of consumer loyalty in social media - a case study', Marketing i Rynek, No 4, 355-361.

22. Stelzner, M. A. (2018). '2018 Social Media Marketing Industry Report'. [online]. [Accessed February 03, 2019]. Available: https://www.socialmediaexaminer.com/so cial-media-marketing-industry-report2018/. 
23. Seemiller, C. and Grace, M. (2013). 'Move over Millennials. Generation $Z$ is Here!', [online]. [Accessed October 17, 2018]. Available: http://advising.arizona.edu/sites/default/f iles/

Move\%20over\%20Millennials\%20Generati on $\% 20 Z \% 20$ is $\% 20$ Here-UPAC.pdf.

24. Sladek, S. and Grabinger, A., (2018). 'Gen $Z$ The First Generation of the 21st Century Has Arrived!', XYZ University, 1-15.

25. Skibiński, A., Sipa, M. and GorzeńMitka, I. (2016). 'An Intergenerational Cooperation In the Organization - View from the Age Perspective', Procedia - Social and Behavioral Sciences, Vol. 235, 412-419.

26. The New Horizon Report. (2008). The New Media Consortium. [online]. [Accessed February 03, 2019]. Available: http://www.nmc.org/pdf/2008-HorizonReport.pdf.

27. Wuest, B., Welkey, S., Mogab, J. and Nicols, K. (2008). 'Exploring Consumer Shopping Preferences: Three Generations,' Family and Consumer Sciences Research Journal 100(1), January 2008, 31-37.
28. Web-1:

https://silleo.pl/blog/2018/08/pokoleniez-wyzwanie-dla-managera/ [Accessed December 03, 2018].

\section{Web-2:}

https://www.kariera.pl/artykuly/pokoleni e-z-kolejne-wyzwanie-dla-hr/ [Accessed December 07, 2018].

30. Web-3:

https://www.enotes.com/homeworkhelp/what-company-profile-what-mustinclude-98901 [Accessed February 03, 2019].

31. Web-4: Business Dictionary. [online]. [Accessed February 03, 2019]. Available: http://www.businessdictionary.com/defini tion/company-profile.html.

32. Web-5:

https://www.ey.com/Publication/vwL UAssets/EY-rise-of-gen-znew-challengefor-retailers/\%24FILE/EY-rise-of-genznew-challenge-for-retailers.pdf [Accessed February 25, 2019]. 